\title{
Critiques of Liberal and Neo-Liberal Arguments in Africa: More Emphasis in Ethiopia: A Systematic Review
}

\author{
Tegegn Nigussie ${ }^{*} \quad$ Zinabu Tesfaw \\ Department of Agricultural Economics, Woldia University, P.O. Box 400, Woldia, Ethiopia
}

\begin{abstract}
Economic liberalism which was founded by Adam Smith is the base for the former liberalism ideology. Through time the present neo-liberalism and capitalist economic system evolved within the liberalism ideology of promoting private ownership of properties and free market for economic development. In this review article, we present the arguments and critiques of liberal and neo-liberal theories to African development more emphasis in Ethiopia. Either in the liberal or neo liberal ideologies believes that government is the second actor on the economy and the market can operate by itself. But for Africa these ideologies are not working because, in Africa still there is not well structure political and economic system. In addition, the market is not still institutionalized enough and there is slow development of infrastructures. Africa cou

ntries should contextualize the liberalism and neo liberalism model of development with the prevailing institutional, social, cultural and political history that every country had internally.
\end{abstract}

Keywords: Liberalism; Neo-liberalism; Argument; critiques; Africa; Ethiopia

DOI: $10.7176 / \mathrm{JESD} / 10-13-05$

Publication date:July $31^{\text {st }} 2020$

\section{Introduction}

The courage of liberalism rooted back to the times of Adam Smith and David Ricardo who advocates free market economy for the growth of nations. Economic liberalism which was founded by Adam Smith in his book entitled with the wealth of nations is the base for the former liberalism ideology (Stegmann, 2004). Through time the present neo liberalism and capitalist economic system evolved within the liberalism ideology of promoting private ownership of properties and free market for economic development.

Neo-liberal ideas that focus on individualism, free markets, and a strong but limited state have so come to dominate advanced industrialized countries' assumptions about what is appropriate political economic action that, up until the economic crisis beginning in 2007-2008, they had all but disappeared from public consciousness and debate. Widely held belief about the benefits of unfettered markets and the dangers of interventionist states, about the importance of market competition and 'competitiveness', about the necessity of liberalizing reform (e.g. deregulation, privatization, labor market flexibility, and welfare state rationalization), and about the imperatives of austerity and structural reform during the Euro zone crisis are all manifestations of the hold of neo-liberal 'background ideas' in contemporary capitalist democracies (Schmidt,2016 ).

The postwar period could be seen as a time infused with a very different set of background ideas, based on principles embedded in a very different approach to markets, the state and society, which are generally associated with neo-Keynesianism and social democracy. But since the 1980s, neo-liberal ideas have become so all pervasive that they have largely receded into the background even as they have served to guide public understandings of the possible and set the limits of the imaginable (Schmidt, 2014).

However, after an initial rapture, disappointment set in as a result of emerging social dysfunction, including high income disparities, detrimental to the sense of social justice. Thus, doubts arose as to whether the newly embraced solutions were indeed the right ones. Economically active individuals became acutely aware of the material limitations to their freedoms, associated with the eroded democratic system and abuse of the fair competition principle (which is fundamental to the free market), mostly due to par monopolistic phenomena. The global financial meltdown that started in the USA in 2007-2008, and which subsequently evolved into an economic downturn and debt crisis, has triggered a tidal wave of criticism of the market economy (Kotz, 2009).

This criticism is often extended to economic liberalism at large, which is fundamentally incorrect and damaging to the advancement of liberal economic and social thought. It must be emphasized that the market is the only viable institutional solution suitable for free democratic societies. There is, and in the foreseeable future there will be, no alternative to the market. Therefore, in its current and evolving form, it will remain the basic institutional mechanism organizing economic processes with their social implications. Given the above, it is essential that the bombardment of criticism of the market economy both in the scholarly literature and in the media, which the global crisis has intensified, should not lead to an indiscriminate condemnation and rejection of liberal economic and social principles. It is those principles that provide the scholarly and ideological foundations for the market, which would completely lose its social orientation without them as Paul Samuelson said "the market has no heart; the market has no brain. It does what it does (Elzbieta,2010).

According to Meles Zenawi (2006) the neo-liberal paradigm is unable to recognize the fundamental market 
failures in the sector that can only be overcome through effective government intervention. Letting markets be free may not produce spectacular results when they are imperfect, but they will at least bring about adequate growth, it was argued. Practice has shown that market failures are as bad as government failures and both have led to a dead end.

Then nowadays, capitalism backed by neo liberalism which promotes strong private ownership of the economy and reducing the role of the government to establish playing fields for the market dominated the world economic system. The objective of this review article is to explain the arguments and critiques of liberal and neoliberal theories for African development, more emphasis in Ethiopia.

\section{Methodology}

In this review the journey through which liberalism and neo-liberalism had discussed based on article review, book review and different previous works. This review also entirely on empirical review on liberalism and neoliberalism the genesis, assumptions, evolution and of the critiques of the theories. Thus, the review is based on a survey of extensive literature review from conceptual to theoretical and empirical evidences. The method of analysis employed in this review is literature content analysis with careful organization and presentation of the result.

\section{Definitions of Liberalism and Neo-liberalism}

Liberalism refers to political, economic, or even religious ideas. In the U.S. political liberalism has been a strategy to prevent social conflict. It is presented to poor and working people as progressive compared to conservative or rightwing. Economic liberalism is different. Conservative politicians who say they hate liberals meaning the political type have no real problem with economic liberalism, including neo liberalism. "Neo" means we are talking about a new kind of liberalism. The liberal school of economics became famous in Europe when Adam Smith, a Scottish economist, published a book in 1776 called The Wealth of Nations. He and others advocated the abolition of government intervention in economic matters. No restrictions on manufacturing, no barriers to commerce, no tariffs, he said; free trade was the best way for a nation's economy to develop. Such ideas were liberal in the sense of no controls. This application of individualism encouraged free enterprise, free competition which came to mean, free for the capitalists to make huge profits as they wished (Elizabeth, 1996). Neo-liberalism is the political ideology which resulted from a few efforts at reinvigorating classical liberalism in the period immediately before and during World War II, by political theorists such as Wilhelm Röpke $(1944 ; 1945)$ and Friedrich von Hayek (1944; Hayek et al. 1935). The main argument is, basically, that these neo-liberals have sought to redefine liberalism by reverting to a more right-wing or laissez-faire stance on economic policy issues, compared to the modern, egalitarian liberalism.

\section{Theories of Liberalism and Neo-Liberalism}

Liberalism and neo-liberalism as political philosophy as well as an economic doctrine have passed across various ups and downs by developing different theories and ideologies in different periods. Thus, neo-liberalism theory is stemmed from liberalism theory by extending some elements of liberal thinking. Liberalism theory characterize by having four foundational aspects namely the autonomous or rationality individual, the state neutrality, the market as a primarily allocator of goods and services and finally that of a state which is limited as a consequence of the first three characterizations. According to some authors, the presence of various schools of liberal thought make difficult for scholars to come up with a single definition of liberalism (Willis, 2005). From the above definition the theory highly advocates that the government must be laissez- faire in the issue of societal decision making process and the market is efficient because of the society is rational decision maker by using supply and demand.

The theory of the present neo-liberalism and capitalist economic system evolved within the liberalism ideology of promoting private ownership of properties and free market. The theory of neo-liberalism is a return and spread of one specific part of the liberal tradition, namely economic liberalism. Economic liberalism is the belief that states ought to abstain from intervening in the economy and instead leave as much as possible up to individuals participating in free and self-regulating markets" (King, 1995;19).

\section{Assumptions of Liberalism and Neo-liberalism theories}

The basic assumption of economic liberalism concerned on four issues. The first one is the economic system flows naturally by itself as it is predetermined by the invisible hands and no way of intervention is necessary by the state. The second is the total abstinence of the state intervention in the economy. Individuals have to be left to do everything and the economic system establishes its own natural flow by itself. The only responsibility of the state is to regulate law and order, keeping security, establishment and maintenance of non-profit institutions such as schools, hospitals, etc. The third point is the economic system is driven by the self-interest of individuals. The provision of products and services by producers is for the sake of their own advantages not for the needs of 
customers. And this self-interest of individuals create strong bond in between and further brought economic wellbeing of nations. The fourth belief of economic liberalism is competition steers the economic order. Every individual is free to compete in the market through his products and services and this brings harmony of the entire community to lead secured life through stabilization of prices without the dominance of one super actor and finally leads to the emergence of what we call capitalism (Stegmann, 2004).

Following classical liberalism, neo-liberalism come to exist with the same ideology of encouraging privatization of economies run by individuals which permit the international competition of service and product provision (Rapley, 2007). This enables the economy to prosper and make prices lower and also advance the efficiency of production and service delivery of competing firms. Neo-liberalism comes to exist in response to the 1970s and 1980s financial crisis and the contentions were the involvement of the government should be eliminated, leaving the economy to market forces, devaluation of currencies and deregulation, privatization and freeing restrictions of markets since the state led development resulted economic failure (Kiely, 2005).

According to Harvey (2005) the tenet of classical liberalism is establishing a strong base of private properties and increasing the roles of private companies to lead and stabilize the economy. The state has limited role of adjusting infrastructures in the market of neo-liberalist ideology and all resource distributions and marketing activities are corrected and improved by the free flow of capital and each individual is concerned on its own interest and also take any of the risks in the market. The free mobility of capital between sectors, regions and countries is encouraged under the realm of neo-liberalism. The barriers of tariffs, penalizing taxation arrangements, environmental controls and location impediments have to be eradicated and this led to the free competition of private enterprises which in turn would result efficiency of production and service delivery (Ibid). in addition, Peet and Hartwick (2009) described the principle of neo-liberalism emerges from the ideology of classical economists and strengthens the avoidance of state intervention in the economy.

The market can establish healthy systems by itself if it is left alone without the hand of the state. The function of the state should be limited at regulating peace and security and safeguarding it externally. According to the logic of free market advocated by neo-liberalism and classical liberalism the problems of inflation, low economic growth and stagnation, the financial bubbles and disruption are all due to government intervention (Due and Phong, 2010). All the economic failures and crises are because of external factors of government intervention not the internal ones and the market has its own regulation mechanism if we left it free to operate by itself (Ibid). In general, as Huang (2011) put it clearly neo-liberalism and classical liberalism are a theory of political economic practice that proposes human well-being can be advanced by the freedom of individual entrepreneurial skills and characterized by free trade, strong property rights and free market. The role of the state is to preserve and create the institutional frameworks which are necessary for the application of the free market economy.

Even if the literal view point and assumption of liberalism and neo-liberalism is as mentioned above, the conspired aim of the ideology was believed by different scholars and politicians as the hegemonic ideology from the early 1980s to the early 2000s. It was the ideology adopted and promoted by American governments since Ronald Reagan. After the turn of the century, however, its intrinsic irrationality, its failure to encourage economic growth in developing countries, its efficacy in concentrating income for the richest $2 \%$ of every rich or developing society that adopted its ideas, and the increased macroeconomic instability as shown by the successive financial crises of the 1990's became clear indications of the exhaustion of Neo-liberalism (Agil Mammadov and Ziyadhan Hasanov, 2016).

\section{Liberalism and Neo-Liberalism in Africa}

Liberalism started in around 1770 but since the early 1970's neo-liberalism had become the dominant political ideology, which is widely spread in every corners of the world. This is so mainly because of the determination of Western powerful states, especially USA and UK to make their domestic political ideology acceptable all over the world and to secure their national interests permanently by establishing international institutions like the International Monetary Fund and the World Bank. As it is obvious, Africa could not escape the influence of these capitalist states. Starting from the second half of the nineteenth century up to the 1960's the Western industrialized states, mainly the European Super Powers, highly exploited the valuable resources of Africa by using their effective military colonization over the continent. And this enabled them to build their military and economic power at a spectacular level, while the source of their prosperity, the continent of Africa, still remains as the poorest continent where the majority of its population has not adequate access to basic economic needs (Tewodros, 2011).

Given their economic structure and conditions, developing nations clearly need international economic relations that depart markedly from the liberal free market approach taken and advocated by industrial nations. This approach is grounded in the principles of free trade tariffs and other devices that distort world market. Instead it is important for developing countries to enjoy discriminatory treatment; that is treatment taking into account of their problems, hence different and more advantageous than that existing between developed countries (Ibid). Shaw's argument reveals the fact that given their economic conditions, it would be impossible for the developing countries to compete with the developed industrial states under the free market policy. It is true that, "without 
market regulation, giant Western Transnational Corporations would continue to monopolize the global economy and profit though speculation and manipulation, while small producers (like African firms) will continue to suffer as a result of these actions" (Fridell, 2006).

According to Bolesta (2019), "the so called global economy is by no means liberal." This can be clearly seen from the way the Western industrialized countries are continually influencing the African states to open their economy for the Western Multi-National Corporations, while they impose so many trade barriers on their imports from Africa. By opposing to the above neo-liberals view, Springer argued that "the structural inequalities of wealth, resources, gender and ethnicity, that are common in the market society, all serve to make the realization of individual freedom problematic" (2010). Because of this, social justice would be the only remedy to realize individual liberty in the market society which is highly identified by the inequalities of wealth, resources. This is true mainly because, social justice is concerned to “distribute society's resources according to some agreed pattern which aimed to enhance equality or increase opportunity, but always by implication to redress a social injustice which occurs because of the enduring social and economic inequalities of say religion, class, gender and/or ethnicity" (Bolesta 2007:13).

Both, Kassongo and Galbraith support the idea that, the first thing that the Africans are striving is not for the abstract political and civil rights; rather they are striving for the realization of basic economic necessities like food and social rights. After that, the next step for Africans would be realizing political and civil rights. Individualism or individual rights, free choice, freedom or civil liberties and democratic accountability are the most important features of liberal democracy (Brenner and Theodore, 2010). Here "individualism implies autonomy and in its extreme interpretation and form can lead to anarchy" (Amadae, 2016). In addition to this, the idea that "individuals can act rationally by divesting themselves of any prior attachment can be seen as a flawed concept with destructive consequences if for example, moral judgment made on such a basis tend to be arbitrary and irrational" (Logan,2017). By doing so, neo-liberals are degrading the status of human being to that of beasts who individually compete for the scarce resources without having an altruistic nature. Tewodros, (2011) argued that individualism which is the invention of Western society is against the metaphysics of developing countries.

So based on different arguments and general facts liberalism and neo-liberalisms are not appropriate for Africa. Because the democratic and the economic systems are not well structured and well-functioning to organized and ruling the market and political actors to operate perfectly. If these ideologies are implemented in Africa without well-structured systems, they will end up with devastating results for the people.

\section{Liberalism and Neo-Liberalism in Ethiopia}

When we come to the case of Ethiopia, comparing to the other Sub-Saharan African states Ethiopia was a little bite late to adopt the Structural Adjustment Programs. This was mainly because from 1974-1991, Ethiopia has been under Dergue regime, which had a socialist oriented ideology (Tewodros, 2011). After the downfall of the socialist government and the transition government took over the power, it prepared a draft of economic policy which foresees Ethiopia as moving towards a market-oriented mixed economy where all forms of ownership and enterprises will operate on the principle of profitability and competitiveness. The cornerstones of the drafted economic policy include limiting the participation of the state sector in the economy; intensifying the role of the private sector; and encouraging popular participation in development (Tesfaye, 1992). The Ethiopian economy needed a transition from a war-economy to a peace economy and from a centrally planned to a market-led economy. In this light the transitional government set out a "New Economic Policy" for the transition period that is aimed to be "consistent with the on-going democratic changes and would consolidate the foundations for the attainment of full democracy (Willem, 1998).

According to PPER, 2000, Ethiopia adopted the Structural Adjustment Programmes in 1992 when the World Bank and then Transitional Government of Ethiopia signed an agreement which is commonly known as the Policy Framework Paper (PFP). With this agreement the Transitional Government of Ethiopia agreed to accept some neoliberal policies like devaluing birr, reducing the role of the state in the economy, to let the market to determine the price of goods and services. But the intention and the action of the government on implementing the Structural Adjustment Programmes is somewhat different. Even though the government of Ethiopia agreed to minimize the role of the government in the national economy, it continued to be the leading actor in the economy. So it is impossible for one to argue that all the neo-liberal policies identified in the Berg's Report are accepted and implemented accordingly.

\section{Impact of market liberalization on Export through currency devaluation}

One of the neo-liberal policies is devaluating currency birr in Ethiopian context as compared to dollar to promote exports and to discourage imports. But according to Yilkal Wassie (2014), devaluation may create contractionary effects through import cost, real balance, income distribution, external debt, speculative demand, trade liberalization, tax, wage indication and cost of working capital changes. Ethiopia depends mainly on exports of agricultural products and the export elasticity of their product is insensitive. In addition to these devaluation 
increases the cost of imported items and raw materials. By doing so, devaluation harms real domestic product in the long run.

According to Hailegiorgis Biramo (2012), when we look at the trends of export performance of Ethiopia before and after trade liberalization the result reveals that imports did increase as a proportion of GDP following trade liberalization. The comparison of imports and exports performance as the percentage of GDP prior to and following trade liberalization shows that imports increased by $86 \%$ while exports by $21 \%$. By and large, the evaluation shows a high deterioration in the trade balance following trade liberalization. Moreover, Ethiopian currency devaluation has a negative effect on Ethiopian export sector due to exports lack the required quality, and hence unable to become competitive in the world market for agricultural products. As a result, Ethiopia remains net importer. The net effects of these combined interactions could currency depreciation and it is a reflection of various economic and policy shocks (Mulluken Nigussie 2016).

The liberal or neo-liberal paradigm states that socially wasteful rent-seeking is the result of government activity and of the size of government activism. It does not distinguish between different types of state activism. This leads it to conclude that most if not all government intervention in the economy is detrimental to growth and hence to suggest that the night watchman state is the best state from the point of view of accelerated growth. But historical practice has shown that state intervention has been critical in the development process. Economic theory has shown that developing countries are riddled with vicious circles and poverty traps that can only be removed by state action. The theory of the developmental state completes the alternative paradigm by showing what type of state can intervene in the economy to accelerate growth while at the same time limiting socially wasteful rentseeking activities (Meles Zenawi, 2006).

According to Tewodros (2011) liberal democracy (neo-liberals, in its contemporary version) cannot help to solve the socio-economic and political problems of Ethiopia. The basic reason is that its principles have been formulated in the industrialized capitalist societies which are characterized by considerable cultural homogeneity and relatively small economic gaps. Accordingly, neither liberal democracy nor revolutionary democracy, but social democracy can effectively address the socio-economic and political problems of Ethiopia. Because in social democracy, government intervention is neither down sized as that of liberal democracy, nor monopolized as that of revolutionary democracy. As we have understood from the above arguments and realities Ethiopia is not benefiting from liberalism and neo-liberalism theories in any ways. Because of the underdeveloped economic and political system which is not capable to undertake free political and economic activities, Ethiopia is better to not adopt the ideologies.

\section{Future direction of Ethiopian economic policy}

The incumbent Ethiopian government intention is to liberalizing the economy by privatizing most of state owned enterprises (organizations) such as telecommunication, civil aviation, financial institutions and sugar corporations etc. To do this reforms and liberalizing the political and economic system, the advocators of liberalism and neoliberalism are giving very huge financial and technical supports. Based on the eagerness of liberalizing the political system, the current government offered calls for all opposition parties and allow them to freely exercise their political opinion throughout the country. But these ethnic based political parties are now causing conflicts throughout the country which is the cause for the death of many innocents, increases the internal displacement and becoming in the position of out of government control. If they move in such a way the continuity of the country is in dangers.

According to Costantinos, 2019, which I also support his ideas, the financial sector are underdeveloped in comparison to some neighbors where part of the population operates in a cashless society. Financial and telecom liberalization is an integral part of the overall economic liberalization, a set of policy measures designed to deregulate and transform the system with the view to achieving a liberalized market-oriented system within an appropriate regulatory framework. Financial sector liberalization in Ethiopia's politics is complex. Hence, the need to justify for politicians resisting the sector's liberalization, the credibility and soundness of the justification and assess the sector's performance compared to other nations.

\section{Conclusions and The Way Forward}

Starting from the second half of the nineteenth century up to the 1960's the Western industrialized states highly exploited the valuable resources of Africa by using their effective military colonization over the continent and forced to accept the liberal political and economic ideologies. But different arguments and general facts liberalism and neo-liberalisms are not appropriate for Africa. Because, democratic and economic systems are not well structured and well-functioning to organize and ruling the market. In addition to this the political actors are unable to operate perfectly. If these ideologies are implemented in Africa without well-structured systems, they will end up with devastating results for the people. The liberal or neo-liberal paradigm is unable to recognize the fundamental market failures in Africa in which different development sectors can only be overcome through effective government intervention. Liberalism or neo-liberalism are not the appropriate political and economic 
ideologies generally for Africa and particularly for Ethiopia. Because, these ideologies are working for the countries that have well established market and political institutions but not Africa which lack these.

Africa including Ethiopia should contextualize the liberalism and neo-liberalism theories of development with the prevailing social, cultural and political history that every country had internally. For Ethiopia, though the developmental state theories is an appropriate economic and political ideology by improving its principle of giving safeguard only for group right to give a concern for individual rights. To do this hybridizing the revolutionary democracy with social democracy to give a concern for individual right which either the developmental state model or revolutionary democracy lacks.

Conflict of interest: The Authors declare that they have no any financial, personal and other relationships that may lead to a potential conflict of interests.

\section{References}

Allaro, H. B. (2012). The impact of trade liberalization on the Ethiopia's trade balance. American Journal of Economics, 2(5), 75-81.

Amadae, S.M., (2016). Prisoners of reason: Game theory and neoliberal political economy. Cambridge University Press.

Asfaw, T. (1992). An Overview of Ethiopia's Planning Experience. The Ethiopian Economy: Structure, Problems and Policy Issues.

Ayen, Y. W. (2014). The effect of currency devaluation on output: The case of ethiopian economy. Journal of Economics and International Finance, 6(5), 103-111.

Barone-Adesi, G., \& Sala, C. (2019). Testing market efficiency with the pricing kernel. The European Journal of Finance, 1-28.

Bolesta, A., (2019). Post-socialist Myanmar and the East Asian Development Model. Central European Economic Journal, 5(1), pp.172-185.

Brenner, N., Peck, J. and Theodore, N., (2010). Variegated neoliberalization: geographies, modalities, pathways. Global networks, 10(2), pp.182-222.

Brenner, N., Peck, J., \& Theodore, N. (2010). Variegated neoliberalization: geographies, modalities, pathways. Global networks, 10(2), 182-222.

Costantinos (2019). A Year into the Third Republic Political \& Socio-Economic Transformation: Where is Ethiopia's Third Reich heading? Public Lecture - Respublica Litereria - RL Vol XIII No 451 MMXIX

David Harvey (2005). Reviewed Work: A Brief History of Neoliberalism

Duc Pham Van and Phong Tran Tuan (2010). The Views of Some Economic Theories on the Economic Crisis of Capitalism and Some Lessons for Vietnam. World Review of Political Economy, Vol. 1, No. 4 (Winter 2010),

Elizabeth Martinez and Arnoldo Garcia, (1996). Both writers attended the Intercontinental Encounter for Humanity and against Neoliberalism, held July 27 - August 3,1996, in La Realidad, Chiapas.

Elzbieta Mączynska, (2010). Classical Liberalism, Neoliberalism and Ordoliberalism1

Fridell, Gavin. "Fair trade and neoliberalism: Assessing emerging perspectives." Latin American Perspectives 33 , no. 6 (2006): 8-28.

Fukuyama, Francis (2006). America at the Crossroads: Democracy, Power and the Neoconservative Legacy. New Haven, Connecticut: Yale University Press.

Gray, John (1995). Liberalism. 2nd Edition. Buckingham: Open University Press.

Hayek, Friedrich A., et al. (1935). Collectivist Economic Planning - Critical Studies on the Possibilities of Socialism. London: Routledge.

Huang Maoxing, (2011). An In-Depth Critical Analysis of Neoliberal and New Imperial Hegemony: Review of "The New Imperialism and A Brief History of Neoliberalism" by David Harvey. World Review of Political Economy, Vol. 2, No. 3 (Fall 2011), pp. 513-520.

Juan Carlos Hidalgo, (2013). The Rise of Emerging Economies: Challenges and Liberal Perspectives. a Policy Analyst on Latin America at the Cato Institute's Center for Global Liberty and Prosperity in Washington, D.C.

Kiely Ray, (2005). Empire in the Age of Globalization: US Hegemony and Neoliberal Disorder, Pluto Press, London.

King, Fraser (1995). Neoliberalism: Theoretical Problems and Practical Inconsistencies, In The promise of Liberalism. Edited by Mike Mills \& Fraser King. Sydney: Dartmouth press.

Kotz, D. M. (2009). The financial and economic crisis of 2008: A systemic crisis of neoliberal capitalism. Review of radical political economics, 41(3), 305-317.

Kristol, Irving (1983). Reflections of a Neoconservative: Looking Back, Looking Ahead. New York: Basic Books.

Logan, B.I., (2017). Globalization, the Third World state and poverty-alleviation in the twenty-first century. Routledge.

Lumuma-Kasongo, Tukumbi (2005). The Problematics of Liberal Democracy and Democratic Process: Lessons 
for Deconstructing and Building African Democracies ${ }^{e e}$ In Liberal democracy and its critics in Africa political dysfunction and the struggle for social change. Edited By Lumuma-Kasongo, Tukumbi. Pretoria: University of South Africa press.

Mammadov, A., \& Hasanov, Z. (2016). NEO-Liberalizm Theory in International Relations.

Naude, W. (1998). On Ethiopia's Economic Transition and Beyond. African Development Review, 10(2), $121-142$.

Nigussie, M. (2016). The Effect of Exchange Rates on Economic Growth in Ethiopia (Doctoral dissertation, St. Mary's University).

Operations Evaluation Department, (2000). Ethiopia Structural Adjustment Programme Project Performance Evaluation Report (Pper)

Peet Richard and Hartwick Elaine. (2009). Theories of Development: Contentions, Arguments

Perry, Marvin (2007) Western Civilization: Ideas, Politics and Society. Newyork: Houghton Mifflin Company.

Rapley John. (2007). Understanding Development: Theory and Practice in the Third World. 3rd ed. Lynne Rienner Publishers, Inc.

Rawls, John. (1993). Political Liberalism. New York: Columbia University Press

Reta, Tewodros. "The Significance of Neoliberalism in the Political Economy of Sub-Saharan Africa: The Case of Ethiopia." PhD diss., Addis Ababa University, 2011.

Röpke, Wilhelm (1944). Civitas Humana - Grundfragen der Gesellschafts- und Wirtschaftsreform. ErlenbachZürich: Eugen Rentsch.

Sartori, Giovanni (1987). The Theory of Democracy Revisited. Chatham, New Jersey: Chatham House.

Schmidt, V. A. (2014). Speaking to the markets or to the people? A discursive institutionalist analysis of the EU's sovereign debt crisis. The British Journal of Politics and International Relations, 16(1), 188-209.

Schmidt, V. A. (2016). The roots of neo-liberal resilience: Explaining continuity and change in background ideas in Europe's political economy. The British Journal of Politics and International Relations, 18(2), 318-334.

Springer, S. (2010). Cambodia's neoliberal order: Violence, authoritarianism, and the contestation of public space. Routledge.

Stegmann Franz. (2004). Economic Liberalism, Marxism and Critical Judgment. St Augustine College of South Africa.

U.S. House of Representatives Committee on Foreign Affairs, Subcommittee on Africa, Global Health, Global Human Rights and International Organizations (2018). Reviewing Current Developments in Ethiopia

Usman, A., \& Bashir, S. (2019). Revisiting the discourse of Globalization, the consensus of Washington, Neoliberalism and the State in Africa. Covenant University Journal of Politics and International Affairs, 7(2).

Willis Katie, (2005). Theories and Practices of Development. London, Routledge.

Wolfson, Adam (2004). "Conservatives and neoconservatives"; The Public Interest 150:3248.

Zenawi, Meles. (2006). African development: Dead ends and new beginnings. Preliminary draft. 